\title{
Profitability and efficiency evaluation of the financial management of a socio-economic intervention
}

\author{
Rosario Cano GARCIA \\ St. Theresa International College, Thailand \\ garciachariec56@gmail.com
}

\begin{abstract}
The role of small businesses is critical in the growth of an economy, and in certain circumstances these necessitate financial aid for their sustainability. The main objective of the study is to evaluate the profitability and efficiency of the financial management of the intervention for the improvement of the socio-economic condition of the small businesses in Santol, La Union, Philippines. The article specifically addressed the functionality of the financial aid relative to the actions taken by the beneficiaries for their small businesses, the profitability and efficiency of financial management condition of the small businesses, and the impact on the socio-economic condition of the small business beneficiaries. The study utilized the descriptive type of research mixing qualitative and quantitative analysis by applying financial ratios. It covered the small businesses from three associations and their 127 members. It was found that the association-beneficiaries deposited the money in a bank before the loaning services. The small businesses became profitable and efficient in utilizing the financial aid. The overall socio-economic impact is good as reflected in the results of their financial management. The small businesses of the associations were able to continue operating and provided loaning services to their needy members. It is concluded that with close monitoring and evaluation, small businesses that were granted financial aid are profitable and efficient in their financial operations. It is then recommended that monitoring and evaluation as well as the provision of interventions for the small businesses be sustained to ensure contribution of small businesses to the economic growth of the society.
\end{abstract}

Key words: profitability, efficiency, financial management, socio-economic intervention.

Please cite the article as follows: Garcia, R. (2017), "Profitability and efficiency evaluation of the financial management of a socio-economic intervention", Management and Marketing. Challenges for the Knowledge Society, Vol. 12, No. 2, pp. 316-333. DOI 10.1515/mmcks2017-0019.

\section{Introduction}

\section{Background of the study}

Small businesses in a free market economy contribute to the development of a society. As more private individuals participate in the management of small businesses, more people are given chances to have sources of living because more employment is generated (Brown, 2017). Small businesses comprise $99.7 \%$ of all types of businesses making their role critical to the growth of the economy (Ingram, 2017).

The United Nations is calling on poor countries to continue eradicating extreme poverty and hunger. Although it proudly reported at the end of the Millennium Development Goals (MDG) period the profound achievement of a more than half decrease of the number of people living in extreme poverty from 1.9 billion in 1990 to 835 billion in 2015, poor countries are expected to make unprecedented 
progress on poverty alleviation in the new development era (The Millennium Development Goals Report, 2015). In response to this call, interventions are provided to communities in order to improve their socio-economic conditions. One particular intervention is the granting of financial aid (Assessing a client's need for intervention (2013). Small businesses are beneficiaries of such intervention aimed to help them increase the capital base and improve their operations.

In Brown 's (2017), he argues that the chance of failure is great for small business owners and that having a small business is also risky. He revealed in the U.S. more than $50 \%$ of small businesses did not succeed in the first year, while about 95\% failed within five years. Moreover, based on survey responses, sixty-one percent (61\%) of the small and medium enterprises that were surveyed did not succeed due to the inability to manage costs, $49 \%$ disclosed not sufficient capital, and $35 \%$ said they did not enough time to manage their accounting books. In a survey conducted on more than 1000 small and medium enterprises, it was revealed that business failure is due to the inability to manage costs, which is a topic of financial management (Waters, 2013). Five out of the eight reasons for the failure of small businesses mentioned by Ames in his book entitled Small Business Management as cited by Mason (2017) point to the difficulty in financially managing the business. The mentioned condition implies that there is a need to provide assistance such as financial aid to small businesses to improve their operations.

Cognizant of the dilemma of small businesses when it comes to financial management especially in regards to insufficient capital, a brief intervention that is granted is financial aid (Assessing a client's need for intervention, 2013). The financial aid for small businesses for its continuous operations is provided because of the mentioned reasons for the failure of businesses of such size relative to financial management.

Focusing on a particular case in northern Philippines, there is a fourth-class municipality identified as Santol in the province of La Union, Region 1 that is being given attention not only by the public, but also the private sector in the development of its thriving small businesses. The municipality of Santol with 11 barangays, has been ranked 658 from among the 1,245 municipalities in the country based on average income (Cities and Municipalities Competitive Index, 2016). It is considered a fourth-class municipality based on the Department of Finance Department Order No. 23-08 that was made effective in 2008 (Philippine Standard Geographic Code, 2016) because of its average annual income of P32 million (Municipality of Santol Profile, 2016). The performance of the municipality in terms of its slow economic dynamism compared to other municipalities implies a need for development, in which an assistance was sought by the local government. Moreover, in the report, there is only one savings and loan association with quasi-banking function as of 2014, and only two registered business groups as of 2015 (Cities and Municipalities Competitive Index, 2016).

The center of commerce and local government of the municipality is Barangay (Brgy) Poblacion (Municipality of Santol, 2016). It evidences development in terms of infrastructure because of the newly opened green market and renovated covered gymnasium in front of the municipal hall in 2016. However, access to Brgy. Poblacion by other 10 barangays as of this writing is difficult 
especially for the small thriving businesses mainly because of the mountainous character of the municipality and financial problems identified by the leaders of the two groups of businesses in the region. Because of the mentioned scenario, the private sector volunteered to provide financial assistance to three groups of associations in 2014 and 2015 for their small business undertakings. After two years of utilizing the financial assistance, the evaluation of the profitability and efficiency of the financial management of the three small associations' small businesses is deemed necessary to determine the sustainability of the community services program of the school that provided the financial grant.

Many studies have been conducted about the municipality of Santol, La Union, Philippines, such as: the Watershed and Water Resources Research Center (n.d.) of Region 1 focused on the Amburayan Watershed; Achieving Food Security: The Role and Constraints Faced by LGUs (Cabanilla, 2002); household and community needs of Barangay Poblacion, Santol, La Union (Paguia et al., 2013); the needs assessment on grassroot leadership in selected barangays in the Municipality of Santol, La Union (Cabauatan, 2013); and integrating community services and research at the countryside of the Philippines focused on the livelihood needs of Sitio Malanas, Lettac Sur, Santol, La Union (Garcia, 2017). However, there was no study ever conducted yet on the impact of a financial intervention for the socioeconomic improvement of the municipality.

An issue can be raised on whether the small businesses that were given financial assistance became successful in terms of profitability and efficiency of financial operations. In addition, the call for continuous development to eradicate poverty, the importance of the role of small businesses in the municipality, and the lack of impact study on financial grant to small businesses in the municipality necessitated this study to be pursued.

\section{Statement of research objectives}

It is the main objective of the study to evaluate the profitability and efficiency of financial management of the financial aid as an intervention for the improvement of the socio-economic condition of the small businesses in Santol, La Union, Philippines.

The research specifically addressed the following concerns:

RQ1: What is the functionality of the financial grant relative to the actions taken by the beneficiary-associations and the individual member-beneficiaries for their small businesses?

RQ2: What is the financial management condition of the small businesses of the beneficiaries (associations and individual members) in terms of: (a) profitability, and (b) efficiency?

RQ3: What is the socio-economic impact of the financial grant?

\section{Scope of the study}

The study covers the three associations with small businesses and their individual member-beneficiaries in Santol, La Union, Philippines. It presents the functionality of the financial grants, and the financial management of the financial grant. The functionality of the financial grant is in terms of the actions taken by the three 
associations, as well as by the individual members. The scope of financial management is on the profitability and efficiency of utilizing the financial grant. The socio-economic impact covers the effect of the grant on the association-beneficiaries and their individual members. The period of operations of the small businesses with the financial grant is for two years (2014 to 2016).

\section{Theoretical framework}

A review of the theories related to the present study is based on the use of the goal setting theory by Edwin Locke in 1968 as cited by Salaman et al. (2005. The theory suggests that the superior performance of an individual is motivated by the goals he sets. In this study, the goal set by the beneficiaries which is to improve their operations became the basis of granting them financial assistance.

This study is also based on the expectancy theory introduced by Victor Vroom in 1964 that was also cited by Salaman et al. (2005). According to this theory, the satisfaction of established valued goals of the individual influences his behavior. Vroom further said that the theory is related to the concept on performance management where the expectation of the effects of future events affects present performance. This is used in the study as the basis of measuring the financial management performance of the beneficiaries where their established goal is about the generation of profit for their business operations to continue.

Another theory that this study is anchored on is the Baumol model of cash management used in inventory and cash management. According to this theory, "a firm attempts to minimize the sum of the holding cash and the cost of converting marketable securities to cash" (Cheriyan, 2013). This theory is used as the basis of the study when determining the efficiency of cash and inventory management by the association-beneficiaries and their members.

This study is also based on the concept of OECD Directorate for Science, Technology and Innovation (2014) of impact assessment. Impact assessment is about the cause and effect of an intervention that leads to the desired results or impact. The evaluation of the profitability and efficiency of the financial intervention granted to the beneficiaries applies this concept on impact assessment.

The concept of performance management is borrowed from the human resource management literature in which for Aguinis (2009) it is defined as "the continuous process of identifying, measuring, and developing the performance of individuals and aligning performance with the strategic goals of the organization." The same concept is applied in the current study on the performance of the association-beneficiaries and their individual members where the performance of utilizing the financial grant is evaluated, however, limited to the profitability, efficiency and impact on socio-economic condition of the beneficiaries.

This study is also grounded in the concept of monitoring and evaluation of extension systems. According to Wongtschowski et al. (2016) the extension services provider can support the beneficiaries in collective buy-in of inputs or marketing, as well as communicating with the local authorities on marketing-related issues. They further contended that the extension services provider can also support women in strengthening their own organizations, such as starting up a new business. In 
addition, the authors mentioned an implication of the use of mixed indicators (qualitative and quantitative) with the local communities. The current study referred to this concept in the evaluation of the use of the financial grant that included the effect on the individual member beneficiaries in strengthening their businesses.

Pound et al. (2011) said that monitoring and evaluating extension services that generated information on the implementation of a project has to also assess the impact of policies and the ability of the stakeholders to have a basis for improved management, decision-making, and accountability. Because of this, the current study provides suggestions on how the association-beneficiaries and their members.

\section{Previous findings in the scientific literature and research gap}

One relevant research on the evaluation of extension services is the study conducted by Taye (2013). He found that positive impacts were mostly reported in the evaluation. However, conflicting reports were noted regarding extension performance. He further said that this was because of overestimated impacts and contradictory results that included the use of poor impact evaluation methodologies, lack of reliable data, as well as the insufficient capacity to conduct rigorous impact evaluations.

Another related study is that of Ammakiw (2013) on the evaluation of extension programs and services of the Kalinga Apayao State College in Tabuk City, Philippines. The findings of his study revealed that the extension programs and services of the institution were "continuing." The impact was 'high' as to political, social, economic, ecological, and cultural aspects. There was a significant difference between the responses of the program implementers and the clientele-beneficiaries on the impact of extension programs and services. Furthermore, the monitoring and evaluation of extension programs was "seldom utilized" although the impact was "high." It was found that the two groups of respondents have significant difference in perception on the impact of the implementation. The problems encountered were found to be "quite serious".

Based on the reviewed literature and studies, there was no impact evaluation on the financial grant as an intervention to improve the beneficiaries of extension services. Most of the evaluation studies on extension services were on agriculture and on monitoring and evaluation of extension programs and services. Although the participants in this study were also engaged in agriculture-related products, the main livelihood activity of the beneficiaries is related to the sale of agricultural products. The beneficiaries are into small business operations especially for SAVA and SMWA but not for SANTODA because the nature of its business is on the operations of tricycle drivers. It is then clear that there is no study yet on the effectiveness or efficiency of the granted financial aid to the small business beneficiaries.

\section{Research model}

The research framework is presented in Figure 1. Four dimensions are noted, such as the input, process, output, and outcome. The input is the financial grant to the 
beneficiaries. The process is related to the functionality or the actions taken in having the financial grant. The determination of the results of using the financial grant is measured in terms of profitability and efficiency of financial management. The socio-economic impact is the outcome of managing the financial grant for the improvement of the small business operations of the beneficiaries, as well as the effect on the individual member-beneficiaries.

\section{Figure 1. The research framework}

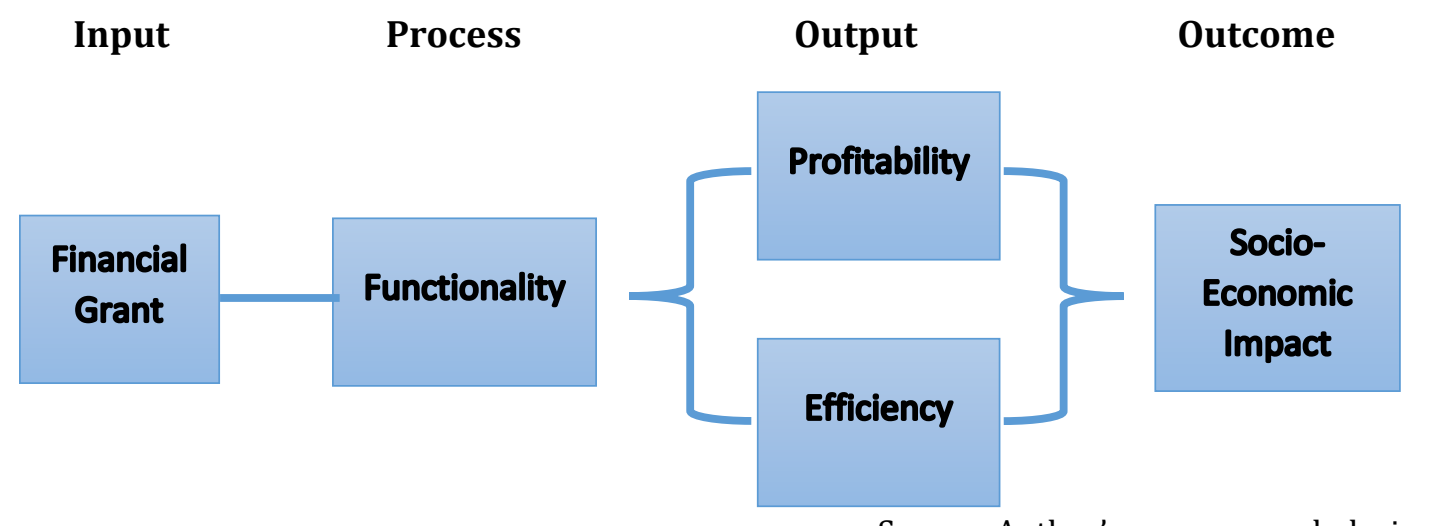

\section{Research methodology}

The descriptive type of research particularly using the mixed method of qualitative and quantitative analysis is utilized in this study. The functionality of the financial grant is described in terms of the actions taken by the beneficiaries. The analysis of financial management is described in terms of profitability and efficiency conditions is utilizing the grant. The socio-economic impact is also determined and described.

\section{Sources of data}

Primary Data. Three groups or associations were asked for information on the utilization and functionality of the financial intervention. Different associations became the beneficiaries, such as Santol Tricycle Operators and Drivers Association (SANTODA), Santol Ambulant Vendors Association (SAVA), and Sitio Malanas Women's Association (SMWA). The number of members who benefited and availed of the credit services of the association-beneficiaries are also known and presented in Table 1.

Table 1. Distribution of beneficiaries

\begin{tabular}{|l|c|c|}
\hline Association-beneficiaries & Number of individual member-beneficiaries & Percentage (\%) \\
\hline SANTODA & 70 & 55.12 \\
\hline SAVA & 32 & 25.20 \\
\hline SMWA & 25 & 19.68 \\
\hline Total & 127 & 100.00 \\
\hline
\end{tabular}


Source: Author's own research.

Secondary Data. The presented written reports such as books of accounts where the financial transactions were recorded served as the secondary data.

\section{Data gathering}

In the gathering of data, a semi-structured tool was used as guide for the interview. The tool was based on the Manual of Extension Services Office of Saint Louis College. The first question was on the action the participants took when they already had the financial grant of P150,000. The second question was on how the grant aided their businesses in continuously operating their business. Another question was on the mechanics of the operations where the grant was included as one of the credit provision services to the members of their associations. The associations were also asked on their individual member-beneficiaries relative to the number of the amount that was granted as credit to them. The last question was on the socioeconomic impact of the financial intervention to the association, as well as to the individual members.

In determining the impact of a financial intervention for the improvement of the socio-economic condition of the residents of Santol, La Union, the extension service team of Saint Louis College coordinated with the local government unit of the province for the said purpose. The team used a semi-structured questionnaire as an interview guide. Three associations with their representatives were asked by the municipal administrator to go to the municipal hall where the interview was conducted. After which the team went to the site of their businesses for the validation of responses to the interview.

The school representatives monitored the utilization of the financial intervention every three months. Communication by the Extension Service Officer with the leaders of the beneficiary-associations was done. An impact assessment team was created, whose main objective was to measure the impact of the financial intervention on the beneficiaries' socio-economic condition. This was also intended to determine the sustainability of their livelihood programs.

The assigned impact assessment team went to Santol, La Union on April 19, 2016. They were accommodated by the Municipal Administrator at the Municipal Hall of Santol, La Union at 2:15 pm. to interview the beneficiary-associations' representatives. Ocular observation of the site of business followed and also interviewed the members for clarifications and validations of answers.

The impact assessment team was composed of the Extension Service Office head and staff - Dr. Leilani Sanidad and Mrs. Angel Cabanban; and Graduate School Professors - Dr. Rosario Garcia, Dr. Wilfred Cabauatan, and Dr. Joseph Cristobal.

The key stakeholders were determined to shed light to the condition before and present. According to EIA Training Manual, one of the analytical tools is the stakeholder analysis (Social Impact Assessment Tools and Methods, 2002). This is because an entry point social impact assessment and participatory work is the stakeholder analysis. Three groups of key stakeholders were identified in this study, foremost was the municipal administrator. This is because they represent the local government. They evidence legal or official transactions. They are the ones to 
facilitate in identifying and interviewing the participants. Another key stakeholder category is that of the leaders or presidents/vice-president of the beneficiaryassociations. They are the ones to share first-hand information to the impact assessment team on the actions taken and the results of using the received financial intervention. They are in the position to answer queries related to the implementation of the project. The representative-members are also important stakeholders. This is because they clarify and validate the responses of the conducted interviews with their leaders.

The Municipal Administrator was Mr. Gery Acorda. With Mr. Acorda were the beneficiaries of the project. Mr. Jaime Camat was the representative of Santol Tricycle and Drivers Association (SANTODA), Mrs. Elizabeth Acorda was the representative of Santol Ambulant Vendors Association (SAVA), and Mrs. Merlita Diao-o was the representative of Sitio Malanas Women's Association (SMWA). The individual members did not like their names to be identified.

\section{Data Analysis}

The gathered data were analyzed qualitatively especially in regards to the behavioral aspect like the impact of the financial intervention on the beneficiary associations and members. There are also some data which were analyzed quantitatively using financial analysis where financial ratios on profitability and efficiency are applied.

The return on capital and return on sales were measured to determine the profitability of using the financial grant. The evaluation of the performance of a business was made for certain periods by computing financial ratios to assess whether there was improvement or deterioration (Pearce and Robinson, 2007). An improvement is a positive change while deterioration is a negative change.

The merchandise turnover was used to measure efficiency. For Pearce et al. (2007), this is determined by comparing revenues with the resources used to generate them. They said that inventory turnover is computed by dividing sales by average inventory. In this study, the word merchandise is used instead of inventory. A turnover greater than one means that the resources like financial resources is utilized for a number of times when it is greater than 1 . The efficiency of using the resource depends on the type of product sold.

Accounts receivable turnover and the average collection period were the other activity ratios used to measure efficiency. Reeves (2011) mentioned that the number of times accounts receivable are paid and replenished in an accounting period represents the accounts receivable turnover. He stated that the faster the business is in collecting its receivables, the higher is the receivable turnover, which means that more cash is generated by the company. The formula for accounts receivable turnover is determined by dividing total net sales by average accounts receivable.

Reeves (2011) also said that another activity ratio that can measure efficiency is the accounts receivable collection period. He stated that this ratio shows the number of days the receivables are collected. Moreover, he said that the company is efficient when it is collecting faster its receivables in fewer days. The 
accounts receivable collection period is computed by dividing 365 days account by accounts receivable turnover.

\section{Data analysis and interpretation Functionality of the financial aid Background of the financial grant}

The need for financial aid was determined through the needs assessment surveys conducted in the first semester of school year 2014-2015 by the Master in Business Administration students in their subject Business Research with a code number of Management 100. They were able to identify particular needs of the three groups of participants, such as: the tricycle drivers, the ambulant vendors, and the members of the women's association of Lettac Sur, Santol, La Union.

The tricycle drivers, who are members of Santol Tricycle Drivers Association (SANTODA) wanted an assistance for their needs. They said that most of the drivers are experiencing difficulty in financing the buying of tricycle parts especially the wheels because they cannot afford the cost of it. Although they already had the association, they still wanted another organization that could give them annual economic benefits. The students proposed to them the organization of a cooperative for the tricycle drivers in which the tricycle officers wanted so much for their 70 active members.

The ambulant vendors of Santol, La Union identified the need to increase the capitalization for their organization called Santol Ambulant Vendors Association (SAVA). This was because the members have small capital and oftentimes experience financial difficulty. They also signify their intent of organizing a cooperative just for the ambulant vendors. This was because the capital of the organization will be increased by the contribution of share capital of every member amounting to at least P500. SAVA has a total of 78 active members.

The residents of Lettac Sur, particularly the women of Sitio Malanas said that they have difficulty in marketing their agricultural products. It was mainly caused by the road to market problem and the limited market that they presently have. Their products are also underpriced especially when they were already about to go home, they give in to the lower prices asked by the buyers. Although a cooperative is in place known as A-Care Cooperative. Not all of them are members of the said cooperative. They said that they need another cooperative for the members of the women's association to uplift their socio-economic condition and help to motivate their children to engage in worthwhile activities sponsored by a cooperative. They have 50 members.

\section{Intervention}

Based on the identified difficulties of the three groups of beneficiaries, which all pointed to financial needs of their small business endeavors, Saint Louis College through its program "Alay Pamaskong Pangkabuhayan" granted a total of P150,000 
(Table 2) as intervention for their socio-economic improvement. The financial aid was awarded to them after the school received all the needed documents like the registration of the current associations in which the beneficiaries are members of. On December 14, 2014, SANTODA and SAVA were granted P50,000 each at the Gymnasium of the Municipality of Santol with the Mayor and other municipal and barangay officials. SMWA was granted P50,000 on September 3, 2015 at Saint Louis College Gymnasium during the Gawad San Luis to the benefactors and beneficiaries of the extension programs. The granting of financial assistance was delayed for SMWA, which was supposed to be on December 14, 2014 because the association failed to submit on time the copy of registration with DOLE or with the municipality.

Table 2. Financial assistance to association-beneficiaries

\begin{tabular}{|l|c|c|}
\hline \multicolumn{1}{|c|}{ Association-Beneficiaries } & $\begin{array}{c}\text { Amount of Financial } \\
\text { Assistance (in pesos) }\end{array}$ & Date Granted \\
\hline SANTODA & 50,000 & December 14, 2014 \\
\hline SAVA & 50,000 & December 14, 2014 \\
\hline SMWA Total & 50,000 & September 3, 2015 \\
\hline \multicolumn{2}{|c|}{150,000} & Source: Author's own research.
\end{tabular}

\section{Actions taken by the association-beneficiaries}

The functionality of the financial intervention was determined in terms of the actions that the beneficiaries took in safekeeping the financial aid and in operating their businesses. The action taken by the association-beneficiaries is distinguished from the action taken by the individual member-beneficiaries. The following discussions are the results of the interviews conducted with the representatives and members of the association-beneficiaries.

Mr. Jaime Camat, the president of SANTODA narrated the actions taken by his group. He disclosed that they deposited the P50,000 grant at Rural Bank of Balaoan for safekeeping. Later the association agreed that P30,000 was to be withdrawn for the purchase of spare parts of tricycles in Balaoan and Bangar, La Union particularly tires and the P20,000 was retained for contingency purposes. Each tire costs an average of P570 pesos. They sold each tire for a profit of P20 to P30 or for a price of P600 each. The association was able to sell 100 tires ever since. The members paid P100 to P200 per day when they were able to pay practicing a policy of "Pay when able." The members were able to pay for a maximum of two weeks. According to the members, they only operate or drive their tricycles three days a week due to the number coding being implemented by the municipality with only 35 members being able to drive half a day.

The vice president of SAVA - Mrs. Acorda revealed that they loaned out to the members all the P50,000 grant. The association collected 1.5\% interest for three months for every loan. The association crafted a scheme that was formulated for the granting of loans. For good payers, P1,500 was granted for the first time borrowing, P3,000 for the second time borrowing, and P5,000 for the third time. Thirty-two (32) members benefited from the loan servicing of the association. The collected P15,000 amount of interest is deposited at Santol Savings Development Association located at Barangay Poblacion, Santol, La Union. 
The president of SMWA - Mrs. Diao-o disclosed that they loaned out P45,000 to members and P5,000 was used as an emergency fund. Twenty (20) members were able to borrow P2,500 each for their livestock business (e.g. piggery), however, five (5) members were able to borrow P5,000 each also for their livestock businesses. The amount of interest for those granted credit amounting to P5,000 for six months was P300, while P150 interest for those who borrowed P2,500 for three months. The emergency fund amounting to P5,000 is currently P2,000. This is because $\mathrm{P} 3,000$ was withdrawn for loaning purposes. The payment of the principal amount by the borrowers was rolled over for the needs of the remaining 25 members.

\section{Actions taken by the individual member-beneficiary}

Seventy (70) active members according to the president of SANTODA revealed that needy members were able to buy on credit from the association the needed spare parts of their tricycles especially tires. A total of 100 tires were sold to the members on credit.

Thirty-two (32) members were able to borrow for their micro vegetableselling businesses according to the vice president of SAVA. The representative members said they were able to purchase kilos of sweet potatoes, rice, vegetables, and others for sale not only from Santol Green Market but also from other areas like Balaoan and Bangar. All of them were able to pay on a weekly basis.

As reported by the president of SMWA, twenty-five (25) members were availed loans. They were able to borrow for their individual micro businesses particularly livelihood needs like the purchase of piglets. One member revealed that he was able to buy one piglet costing around P2,000. The remaining amount (P500) was used for the feeds, starter, grower, antibiotic, and for deworming (purga) of the pigs for over four (4) months. Twenty members were granted loan amounting to P2,500 each and five (5) were granted P5,000 each.

\section{Profitability and efficiency of utilizing the financial aid}

The financial aid had impact not only to the beneficiary -associations but also to their individual members in terms of their socio-economic condition. The impact is measured in terms of utilizing financial ratios on profitability and efficiency. Profitability is measured in terms of the return on capital and return on sales; while efficiency is in terms of merchandise turnover, accounts receivable turnover, and average collection period.

Profitability and efficiency of using financial aid for the association-beneficiaries The three beneficiary associations - SANTODA, SMWA, and SAVA were able to have an improved economic condition through the interest on loans that increased the seed money that was granted to them. The following were orally reported with written documents by the representatives of the beneficiaries in the presence of the municipal administrators and the extension services team of SLC. Table 2 shows the amounts that were granted as financial aid and the amounts as of 2016.

SANTODA was able to earn a total amount of interest of P3,000. For 17 months the association was able to generate a 6\% (P3,000 interest/P50,000 capital) 
growth rate, which is also interpreted as the return on capital from their loaning operations.

SAVA, seventeen (17) months after the granting of the P50,000 Alay Pamaskong Pangkabuhayan earned P15,000 from the collected interests on loans or a total capital of P65,000. The amount is deposited at Santol Savings Development Association. It generated an increase in capital of $30 \%$.

SMWA was able to generate an income of P5,000. It is equivalent to $10 \%$ increase in capital or P5,000 interest/P50,000 capital. The increase in income was generated for about 7 months from the granting of P50,000 by SLC. At present, the total capital is P55,000.

One way to measure the economic impact to the beneficiary-associations is by using financial ratio on profitability called return on capital. The return on capital for Brigham and Houston (2009) is determined by dividing profit by capital. In this study, capital is the difference between the capital in 2016 divided by the amount of financial intervention in 2014-2015. Comparing the economic impact to the two association-beneficiaries in Table 3, the return on capital for the P150,000 financial intervention is $15.33 \%$ and an average monthly return on capital of $1.18 \%$. SANTODA and SAVA utilized the financial intervention as seed money for their businesses for 17 months with $6 \%$ and $30 \%$ respectively as return on capital. Computing the monthly return on capital results to $0.35 \%$ and $1.76 \%$ every month respectively. SMWA, the third beneficiary-association, utilized the grant just for 7 months and was able to generate a $10 \%$ return on capital with $1.43 \%$ every month. Apparently, it is SAVA that earns the most among the three beneficiary-associations. This can be explained by the fast turnover of merchandise of the association, in which according to the president and vice-president of SAVA, they bring their products to the customers because they are ambulant vendors.

Table 3. Return on capital of financial aid to beneficiary-associations

\begin{tabular}{|l|c|c|c|c|}
\hline \multicolumn{1}{|c|}{ Beneficiaries } & $\begin{array}{c}\text { Financial Aid } \\
\text { Granted in 2014- } \\
\text { 2015 } \\
\text { (in pesos) }\end{array}$ & $\begin{array}{c}\text { Amount of } \\
\text { Capital } \\
\text { in 2016 } \\
\text { (in pesos) }\end{array}$ & $\begin{array}{c}\text { Return on } \\
\text { Capital } \\
\text { (in percentage) }\end{array}$ & $\begin{array}{c}\text { Monthly Return } \\
\text { on Capital } \\
\text { (in percentage) }\end{array}$ \\
\hline $\begin{array}{l}\text { SANTODA (17 } \\
\text { months) }\end{array}$ & 50,000 & 53,000 & 6.00 & 0.35 \\
\hline SAVA (17 months) & 50,000 & 65,000 & 30.00 & 1.76 \\
\hline SMWA (7 months) & 50,000 & 55,000 & 10.00 & 1.43 \\
\hline Total & 150,000 & 173,000 & & 1.18 \\
\hline Growth Rate & & & 15.33 & \\
\hline
\end{tabular}

As can be gleaned from Table 4, the association-beneficiaries were able to grant credit for many times to their members for their own small businesses. The financial activity financial ratios that are used are the accounts receivable turnover, and average collection period. Accounts receivable turnover for Reeves (2011) is about the number of times accounts receivables are collected and replenished during the accounting period, while the average collection period is about the number of days the receivables are collected. It appears that SAVA with 52 times had the most turnover for its receivables because it was able to collect every week 
or for 7 days. SANTODA came second to SAVA in terms of the receivable turnover. This is due to the full collection of receivables for two weeks or 14 days. SMWA has the longest period of collection period since it has its receivable turnover for only 4 times since the start of their operations with the financial aid. This can be explained by the waiting period to be able to sell a livestock which is for about four months for the member-borrower to be able to pay his credit to the association.

Table 4. Efficiency analysis of the financial grant

\begin{tabular}{|l|c|c|c|c|}
\hline $\begin{array}{c}\text { Association- } \\
\text { Beneficiaries }\end{array}$ & $\begin{array}{c}\text { Amount of } \\
\text { Credit } \\
\text { Receivables (in } \\
\text { pesos) }\end{array}$ & $\begin{array}{c}\text { Amount of } \\
\text { Credit Sales (in } \\
\text { pesos) }\end{array}$ & $\begin{array}{c}\text { Receivable } \\
\text { Turnover }\end{array}$ & $\begin{array}{c}\text { Average } \\
\text { Collection } \\
\text { Period }\end{array}$ \\
\hline SANTODA & $1,265.60$ & 33,000 & 26 times & 14 days \\
\hline SAVA & $1,246.00$ & 65,000 & 52 times & 7 days \\
\hline SMWA & $16,438.36$ & 50,000 & 4 times & 120 days \\
\hline \multicolumn{1}{|c|}{ Total } & $18,949.96$ & 148,000 & & \\
\hline
\end{tabular}

Source: Author's own research results.

Profitability and efficiency of using financial aid for the individual member-beneficiary The individual members of the different associations were also economically benefited by the financial intervention. The impact to the individual memberbeneficiary is measured in terms of financial ratios on profitability and efficiency. The applied profitability ratios are return on sales and return on capital, while for efficiency is the merchandise turnover.

Analyzing the financial performance of the three associations, the return on sales by Frase and Ormiston (2004) is determined by diving profit by sales. Applying the financial ratio in this study, it can be gleaned from Table 5 that SMWA had the highest return on sales, followed by SANTODA and last is SAVA. From the conducted interviews, it was disclosed that before the grant of P50,000, each tricycle driver of SANTODA earned a range of P100-P200 per week. The drivers at present are able to purchase on credit the spare parts particularly tires at the association, which is located at Barangay Poblacion, Santol, La Union. At present each driver is already earning more than before, which is within the range of P200P300 weekly income or an increase of at most $50 \%$ with also a $50 \%$ return on sales. This is because they did not have to go to the Municipality of Balaoan or Bangar to buy their needs costing them additional expenses on transportation and time.

Table 5. Profitability and efficiency financial ratio analysis

\begin{tabular}{|l|c|c|c|c|c|c|c|}
\hline $\begin{array}{c}\text { Individual } \\
\text { Member- } \\
\text { Beneficiary }\end{array}$ & $\begin{array}{c}\text { Amount } \\
\text { Borrowed } \\
\text { (in pesos) }\end{array}$ & $\begin{array}{c}\text { Amount } \\
\text { of Sales } \\
\text { or } \\
\text { Income } \\
\text { (in } \\
\text { pesos) }\end{array}$ & $\begin{array}{c}\text { Amount } \\
\text { of } \\
\text { Expenses } \\
\text { (in } \\
\text { pesos) }\end{array}$ & $\begin{array}{c}\text { Profit } \\
\text { (in } \\
\text { pesos) }\end{array}$ & $\begin{array}{c}\text { Return on } \\
\text { Sales } \\
\text { (in } \\
\text { percentage } \\
\text { ) }\end{array}$ & $\begin{array}{c}\text { Return on } \\
\text { Capital } \\
\text { (in } \\
\text { percentage) }\end{array}$ & $\begin{array}{c}\text { Merchandise } \\
\text { Turnover } \\
\text { (number of } \\
\text { times) }\end{array}$ \\
\hline $\begin{array}{l}\text { SANTODA } \\
\text { member }\end{array}$ & 150 & 300 & 150 & 150 & 50.00 & 100.00 & 2 times \\
\hline
\end{tabular}




\begin{tabular}{|l|c|c|c|c|c|c|c|}
\hline $\begin{array}{l}\text { SAVA } \\
\text { member }\end{array}$ & 1,500 & 1,845 & 1,500 & 345 & 18.70 & 23.00 & 1.23 times \\
\hline $\begin{array}{l}\text { SMWA } \\
\text { member }\end{array}$ & 2,500 & 7,000 & 3,125 & 3,875 & 55.36 & 155.00 & 2.8 times \\
\hline \multicolumn{1}{c|}{ Total } & 4,150 & 9,145 & 4,775 & 4,370 & & & \\
\hline \multicolumn{1}{|l|}{ Average } & & & & & 47.79 & & 2.2 times \\
\hline
\end{tabular}

Source: Author's own research results.

More ambulant vendors were able to borrow from SAVA as disclosed by the officers. This is because of the increase in capitalization from P75,000 provided by the local government unit of Santol, La Union to P125,000. However, the financial intervention amounting to P50,000 benefited 32 members. They were able to have more income because of the additional funds from loans. For first time borrowers, a $1.5 \%$ interest on P1,500 credit amounts to P22.5. An industry practice is to add a mark-up of around 20\%-25\% to the cost as profit using the cost-plus profit pricing strategy. That would amount to an aggregate price of P1,845 or a profit of P345 with $18.70 \%$ return on sales.

At Sitio Malanas, Mrs. Dia-o reported that each member was financially assisted. She said that a member, who was able to borrow P2,500 was able to buy one piglet amounting to P2,000. After four months, the pig is sold at an amount ranging from $\mathrm{P} 6,750$ to $\mathrm{P} 7,000$. Income from sales is about $350 \%$ of cost. Considering incidental expenses, such as P5 for deworming, P10 for the antibiotic, P750 for the feeds and starter, and P375 for grower, the total amount of expenses per pig for over four months is P1,125. The total amount of expenses is P3,125. So, $\mathrm{P} 7,000$ less $\mathrm{P} 3,125$ is equal to $\mathrm{P} 3,875$ with $155 \%$ return on capital and $55.36 \%$ return on sales. The high return on capital was only based on the operating expenses on cost of purchase and incidental expenses. It did not include the rent expense, the salary and wages expense, power and utility expense, and the interest expense. The reason according to the president of SMWA for not including the mentioned other expenses was because the member-borrowers had the piggery business in their own backyards which are considered as just opportunity costs. Frank and Bernanke (2013) considered the opportunity cost as the value of the foregone alternatives which should not be taken as beyond the cost of the alternatives in which the implicit cost is a part of.

Based on the analysis in Table 5, it can be deduced that the SMWA member gained the highest amount of profit, followed by SANTODA member. In reference to a financial ratio known as merchandise turnover, which for Brigham and Houston (2009) is about the number of times merchandise is sold and replenished, can be used to measure the efficient management of merchandise. They said that it can be determined by dividing sales or cost of goods sold by inventory. In a simple prospect in this study, inventory is tantamount to the amount borrowed since it is also the amount that is used in the purchase of inventory.

A critical efficiency measurement of the performance of a business is the determination of the speed with which a company can sell merchandise (Investopedia, 2017). Moreover, it has meaning when profit is realized on sales. It can be deduced from Table 4.2.2 that profit is generated by the three associations making their merchandise turnover very relevant. As further applied in this study, 
merchandise turnover considers the length of time sales are completed, the merchandise of SAVA member compared to SMWA appeared to have lower profit on sales had the lowest return on sales among the three associations because of the small volume of sales and a low merchandise turnover. The sales of a SMWA member, appearing to have the highest profit on sales and with the highest merchandise turnover can only be received after four months, and while the income of a SANTODA member is only received three times a week with a slightly low merchandise turnover than SMWA.

\section{Socio-economic impact}

Based on the analysis on the impact of the financial intervention to the small businesses of the three beneficiary-associations and their individual members, the objective of improving the socio-economic condition was attained. The intervention of financial aid can be described as effective. This is due to the increase in the amount of their capital and a return on capital for almost two years utilization of $15.33 \%$ for the three associations, while a return on sales of $47.79 \%$ for the individual member-beneficiary.

As to the impact on behavior of the members, changes were also noted. The members of SANTODA became closer to the association because of the ready financial assistance. The president of the association said that the members became more united because of the immediate addressing of individual needs. The SAVA members became grateful to the provided additional credit services according to the vice president of the association. She further said that the members who benefited by the grant were financially hard up before and now they are continuing their individual businesses as ambulant peddlers. The representative of SMWA disclosed that they became inspired to have individual business activities venturing in livestock raising.

An overall positive impact can also be noted on the associations, as well as to their members in terms of the noted change in the services the associations provided to the small businesses of their individual members. This is because instead of going to farther places just to buy tires, the members of SANTODA can already have the tires from their association, in which the business is located at their office. For SAVA, more members were already able to avail of credit resulting to more services provided by the association to more members. SMWA members were motivated to have their individual businesses because of the borrowed capital from the association.

\section{Conclusions}

The provision of financial aid to small businesses in Santol, La Union proved that intervention is necessary for them to continually operate especially so in addressing the needs of the individual members, who are also into their own small businesses.

The study revealed that the financial aid assisted the beneficiaries in continuing to provide their members the needed services, which is specifically on their financial needs to purchase the necessary supplies. The augmented capital from the financial grant enables small businesses to cover for the needs of more 
members. The profitability and efficiency of the small businesses are not solely due to the financial aid but also to the diligence of the leaders of the association to see to it that the needy members are given assistance which is credit provided in acceptable terms and conditions to ease out their financial difficulty.

It can also be concluded that the small businesses can be assisted in improving their operations through a financial aid. The socio-economic condition of the beneficiaries (associations and the individual members) greatly improved because of the continuous operations of the credit services, as well as the closer relationships between the associations and their members in using the financial grant.

It can be further concluded that through close monitoring and evaluation of assistance in coordination with the government institution and the provider of financial aid, the financial intervention can be very useful to the growth of small businesses, thereby improving the socio-economic condition also of the community.

It is then recommended that the monitoring and evaluation of intervention particularly the financial aid should be given attention and be done periodically. An impact assessment should be conducted beyond a year. It should be with specific criteria like measuring the profitability and efficiency of financial operations that were provided intervention. This is done in order to find out if the intervention is working or not.

The small businesses whose operations became profitable and efficient should be further guided and assisted to sustain growth and development of the society and to help the country decrease poverty and hunger.

\section{References}

Ammakiw, J. S. (2013), "Evaluation of extension programs and services of the Kalinga, Apayao State College, Tabuk City, Philippines", International Journal of Advanced Research in Management and Social Sciences, Vol. 2, No. 12.

"Assessing a client's need for intervention" (2013). Retrieved from: etraining.community door.org.au/mod/page/view.php?id=97.

Brigham, E. and Houston, J. (2009), Fundamentals of financial management, Mason: Cengage Learning.

Brown, M.J. (2017), "How important are small businesses to local economies?", Retrieved from: smallbusiness.chron.com/important-small-businesses-localeconomies-5251.html.

Cabanilla, L.S. (2002), "Achieving food security: The role of and constraints faced by LGUs", PASCN Discussion Paper, University of the Philippines. Retrieved from: pascn.pids.gov.ph/ files /Discussions\%20Papers/2002/2002-07.pdf.

Cabauatan, W.F. (2013), "Needs assessment on grassroots leadership in selected barangays in the Municipality of Santol, La Union", Saint Louis College Faculty Research Journal, Vol. X, No. 1.

Cheriyan, N.K. (2013), "Theories in financial management", Retrieved from: thecommercepedia.blogspot.com/2013/03/theories-in-financialmanagement.html. 
Cities and Municipalities Competitiveness Index (2016). Retrieved from: www.competitive.org.ph.cmcindex/pages/province/?province=La\%20Union

Frank, R.H. and Bernanke, B.S. (2013), Principles of economics, fifth edition. New York, USA: Mc-Graw Hill/Irwin.

Frase, L. and Ormiston, A. (2004), Understanding financial statements, New Jersey: Pearson Prentice Hall.

Paguia, D. and Garcia, R. (2013), "Household and community needs of Barangay Poblacion, Santol, La Union", Saint Louis College Faculty Research Journal, Vol. $\mathrm{X}$, No. 1.

Garcia, R.C. (2017), "Integrating community services and research: A livelihood needs assessment at the countryside of the Philippines", Journal of Education and Practice, Vol. 8, No. 3.

Ingram, D. (2017), "The advantages of businesses in the local economy", Retrieved from: smallbusiness.chron.com/advantages-businesses-local-economy-3289. html.

Investopedia (2017) Retrieved from: www.investopedia.com/terms/i/inventory turnover.asp\#ixzz 4iBE5aEjD.

Mason, M.K. (2017), “What causes small businesses to Fail?”, Retrieved from: www.moyak.com/papers/small-business-failure.html.

Municipality of Santol (2016). Retrieved from: www.launion.gov.ph/page.php?132.

OECD Directorate for Science, Technology and Innovation (2014), "Assessing the impact of state interventions in research - Techniques, issues and solutions", Retrieved from: www.oecd.org/sti/inno/What-is-impact-assessment-OECD Impact.pdf.

Pearce, J.A. II and Robinson, R.B.Jr. (2007), Strategic management: Formulation, implementation, and control, tenth edition, New York: McGraw-Hill.

Philippine Standard Geographic Code (2016) Retrieved from nap.psa.gov.ph/ activestats/psgc/articles/con_income.asp.

Pound, B., Gündel, S., Martin, A. and Apenteng, E. (2011), Metaevaluation of extension evaluation, Switzerland: Lindau.

Reeves, H. (2011), "Financial statement analysis for small Businesses: A resource guide", Virginia Small Business Development Center Network. Retrieved from: www.hrsbdc.org/wp-content/uploads/2011/04/VSBDCFinancialStatement ResourceGuide.pdf.

Salaman, G., Storey, J. and Billsberry, J. (2005), Strategic human resource management: Theory and practice, second edition, Sage Publications.

Social Impact Assessment Tools and Methods (2002) Retrieved from: unep.ch/etb/ publications/EIA_2ed/EIA_E_top13_hd1.PDF.

Taye, H. (2013), "Evaluating the impact of agricultural extension programmes in sub-Saharan Africa: Challenges and prospects", African Evaluation Journal, Vol. 1, No. 1.

The Millennium Development Goals Reports (2015). Retrieved from: www.un.org/ millenniumgoals/reports.shtml.

Waters, C. (2013), "Top reasons for small business failure: Study", Retrieved from: www.smartcompany.com.au/growth/top-reasons-for-small-businessfailure-study. 
Watershed and Water Resources Research Center (n. d.) Ecosystems Research and Development Bureau. WWRRC-REGION 1 Ecosystems Research Station. San Fernando City, La Union, Philippines. Retrieved from: erdb.denr.gov.ph/index.php/about-erdb/research-center/watershed-andwater-resources-research-center.

"What is impact assessment?" (2014) Retrieved from: www.oecd.org/sti/inno/What-is-impact-assessment-OECDImpact.pdf.

Wongtschowski, M., Oonk, L. and Mur, R. (2016), "Monitoring and evaluation for accountability and learning", KIT Working Paper 2016:3. Retrieved from: 213ou636sh0ptphd141fqei1-wpengine.netdna-ssl.com/sed/wpcontent/uploads/sites/2/2016/03/WPS_3-2016-web.pdf. 